\title{
Laboreal
}

Volume 11 №2 | 2015

Varia

\section{Intervenção no XI Congresso Internacional de Psicotécnica}

Intervención en el XI Congreso Internacional de Psicotécnica

Intervention au XIème Congrès International de Psychotechnique

Speech at the Eleventh International Congress of Psychotechnics

\section{Georges Friedmann}

\section{(2) OpenEdition}

Journals

\section{Edição electrónica}

URL: http://journals.openedition.org/laboreal/3782

DOI: $10.4000 /$ laboreal.3782

ISSN: 1646-5237

\section{Editora}

Universidade do Porto

\section{Refêrencia eletrónica}

Georges Friedmann, «Intervenção no XI Congresso Internacional de Psicotécnica », Laboreal [Online], Volume $11 \mathrm{~N}^{\circ} 2$ | 2015, posto online no dia 01 dezembro 2015, consultado o 24 setembro 2020. URL http://journals.openedition.org/laboreal/3782 ; DOI : https://doi.org/10.4000/laboreal.3782

Este documento foi criado de forma automática no dia 24 setembro 2020.

\section{(c) (†) \&}

Laboreal está licenciado com uma Licença Creative Commons - Atribuição-NãoComercial 4.0 Internacional. 


\title{
Intervenção no XI Congresso Internacional de Psicotécnica
}

\author{
Intervención en el XI Congreso Internacional de Psicotécnica \\ Intervention au XIème Congrès International de Psychotechnique \\ Speech at the Eleventh International Congress of Psychotechnics
}

Georges Friedmann

\section{REFERÊNCIA}

Texto original:

Friedmann, G. (1954). Intervention au XIème Congrès International de Psychotechnique (Psychologie appliquée), Section de psychologie du travail, Paris, 1953. Le Travail Humain, 17, 1-2, 39-40.

1 O Dr. Frisby sublinhou justamente, na conferência do Prof. Hearnshaw, que a obrigação, a imposição e a disciplina constituem a essência do trabalho, podendo este último ser definido, em última análise, como uma atividade em que intervém um elemento de imposição. Existe, evidentemente, uma grande variedade de imposições e não resulta automaticamente que uma atividade exercida nessas condições não possa comportar diversas formas de satisfação. Espero que a discussão permita retomar este assunto e, pela parte que me toca, salientarei na exposição do Sr. Hearnshaw, juntamente com alguns comentários, os seguintes pontos:

2 1. É consensual que a conceção de uma psicologia industrial, que seria uma simples utilização de técnicas «aplicadas» à vida económica e, em especial, à vida industrial, é exígua e limitadora. Há que salientar que as ciências do homem, que constituem as mais recentes, suscitaram analogias erradas com as ciências psicomatemáticas. Existiria uma psicologia aplicada à vida industrial, derivada da psicologia teórica, como existe, em relação à teoria física, uma termodinâmica e uma mecânica aplicadas, ou uma eletricidade industrial: conceção que, de resto, implica uma dicotomia arbitrária entre 
a teoria e a prática. Saliente-se, a este respeito, as confusões geradas pelo próprio termo «psicotécnica», que foi objeto de discussão no Congresso de Göteborg.

Para o Sr. Hearnshaw, que rejeita esta conceção, a psicologia industrial é uma ciência onde distingue 3 aspetos:

a. Um conjunto de fins e de princípios;

b. Um conjunto de conceitos teóricos;

c. Um corpo de técnicas.

Mas esta própria divisão, e talvez Sr. Hearnshaw pudesse salientá-lo, é didática e um pouco artificial no sentido de que a aplicação das técnicas, o respetivo desenvolvimento, a sua comprovação através da experiência repercutem-se constantemente nos conceitos teóricos, modelam-nos e modificam-nos numa incessante ação recíproca. Facto que J. M. LAHY muito bem expressou num artigo notável sobre higiene mental (Hygiène mentale) (dezembro de 1932), quando escreveu: «A psicologia aplicada ou psicotécnica não é senão a psicologia científica geral. Não só esta não difere da psicologia teórica, mas, fruto desta, ultrapassa-a, transforma-a e vai substituí-la como o produto da sua evolução necessária, como uma síntese da teoria com uma nova prática.»

5 2.. A psicologia industrial não pode ser uma coleção de aplicações e tal, no nosso entender, sobretudo porque o trabalho é uma realidade original, global, una, que não pode ser avaliada, absorvida, compreendida por pretensas «aplicações», dispersas de uma ciência «pura». Há que insistir aqui no caráter uno e complexo dos conteúdos do trabalho.

Independentemente da tarefa, observada concretamente nas oficinas, escritórios, estaleiros, na agricultura moderna, esta apresenta-se sob 5 aspetos ou características principais: técnica, fisiológica, psicológica, social e económica. Cada um destes aspetos expressa a mesma realidade vista sob diferentes ângulos e em toda a sua riqueza de conteúdo. As reações mentais de um operário, Paul, numa determinada oficina, no conjunto das suas tarefas quotidianas e, inversamente, o seu esforço para modelá-las de acordo com as suas características pessoais revelam, a propósito do que se convencionou denominar «aptidões», «dedicação laboral», «satisfação» ou «insatisfação» que não existe, indubitavelmente, um único problema relativo ao trabalho humano que seja meramente psicológico.

7 Explicam-se, desta forma, a relatividade e também determinadas deceções e erros do método dos testes que foi frequentemente aplicado na indústria ao longo dos últimos vinte anos. Explicam-se também, assim, a relatividade e as desilusões de vários estudos que visavam compreender os fenómenos do «tédio», da «monotonia», e mesmo a «fadiga», fenómenos que suscitam também, evidentemente, condições técnicas, económicas e sociais. As investigações em matéria de sociologia industrial confrontamnos permanentemente com a inter-relação dos diversos aspetos do trabalho e revelam a necessidade de uma colaboração estreita de equipas de investigadores pertencentes às várias ciências dedicadas ao trabalho humano.

8 Por conseguinte, garantem-nos que qualquer «política da produtividade» que ignorava ou negligenciava esta inter-relação seja, mais tarde ou mais cedo, condenada ao fracasso. Permitam-me acrescentar, concordando com a Sra. PACAUD, que ela não merecia a colaboração de psicólogos industriais preocupados em não comprometer a 
respetiva atividade ao serviço de interesses particulares e de mantê-la num campo científico. 